\title{
Pesantren-Based Counseling in Changing The Behaviour of The Community of Former Bajingan Being Personal Characterless "Pelopor"
}

\author{
Samsul Arifin \\ Da'wah Faculty, Universitas Ibrabimy Situbondo, Indonesia \\ *Corresponding author:syamsulahasan@ibrabimy.ac.id
}

Article history

Received: 2020-03-18 Received in revised form: 2020-05-06 Accepted: 2020-05-30 Published online: 2020-10-30

\begin{abstract}
The kiai (muslim scholars of Islamic knowlegde disciplines in Indonesia) and the bajingan (bandit, local strongmen, and gangsters) have a positive relationship. Even kiai able to utilize their potential for the common good. Kiai can change the behavior of the former bajingan being personally "Pelopor", which is characterized as a leader in preaching and build civilization together with the surrounding communities. The focus of this paper: the quality rather than the personality of the counselor, procedures, and stages in counseling, and behavior that characterized the former bajingan "Pelopor". The study used a qualitative-ethnographic approach. Data derived from the documents and field notes. The results of this study are to construct attawazun (balance), according to the characteristics of the Islamic boarding school. On the quality of personality counselor balance between quality shalabiyyah (scientific prowess and skills) with shalih integrity (strength of character). On delivering a message, the balance between targhib (reinforcement) and tarbib (punishment). In the former bajingan behavior change, the balance between ritual piety and social piety
\end{abstract}

Keywords: Counseling, kiai, bajingan, pelopor 


\subsection{INTRODUCTION}

In research sheets, "bajingan" (bandit, local strongmen, and gangsters) or "blater" (in the context of the eastern Madura community, Indonesia) is always portrayed with "blurred" portraits as heroes, hobbies of cockfighting and cow bullies, gamblers, murderers, robbers, and criminals the other. They are also the authorities and have a strong position in the social strata because they are good at managing the security of the surrounding community (Hasan, 2003; Hudaeri dkk, 2002; Kosim, 2007; Pribadi, 2014; Raditya, 2011).

Bajingan and kiai (muslim scholars of Islamic disciplines in Indonesia) are among the highest social strata in society. The relation between the kiai and the bajingan is sometimes very contrasting, but also often very harmonious. Symbolic images of rogue violence and religious kiai's interconnectedness and dialogue with Madura's social spaces (Kosim, 2007; Raditya, 2011; Rozaki, 2004).

In the context of the Besuki residency community, Indonesia (Situbondo, Bondowoso, Jember, and Banyuwangi), the kiai and the bajingan also have a relationship. Even the kiai utilize the power of the bajingan for the benefit of Islamic da'wah. For example in Pondok Pesantren (Islamic boarding school) Salafiyah Syafi'iyah Sukorejo Situbondo. Since its establishment, this pesantren has utilized the power of the bajingan to "benefit" the pesantren, Islamic da'wah, and the struggle to defend the independence of the Republic of Indonesia.

Kiai of Pesantren Sukorejo collects former bajingan in the "Pelopor" container. They also succeeded in changing the bajingan's behavior into a person with the character "Pelopor". The term "Pelopor" comes from the syllable "fa" meaning pemimpin (leader), "lam" means lillah (because of God), "fa" means pemimpin (leader), "ra" means rakyat (people); namely, a person who can be a leader in the way of Allah (da'wah) and a leader who fights for the people for prosperity and happiness in the afterlife. The change in behavior is thanks to "counseling" (although the kiai refer to it as da'wah activities) by the kiai (Arifin, 2014a, 2018a; Hasan, 2003).

Counseling is an applied science, therefore the search for local wisdom is very important. Counseling which has been dominated by theories from the West, in the application in the field often experiences obstacles; because many are not following the culture of the local community. Some counseling experts finally made an offer so that counseling gives space to local cultural values and must always be innovative in incorporating issues of diversity and spirituality into the counseling process (Henriksen, 2015; Maurice, 2010; Saruhan, 2019). One approach to counseling that is based on Indonesian culture and religion, is counseling derived from the values of the pesantren tradition.

The theoretical framework in this study uses the perspective of indigenous counseling theory. Indigenous counseling presents an approach to the context (family, social, cultural, and ecological) content (meaning, values, and beliefs) explicitly incorporated into the research design. Kim said indigenous psychology is a scientific study of natural human behavior or thoughts that are not transported from other regions and are designed for the people. Thus, the indigenous counseling advocates to examine the knowledge, skills, and beliefs that people have about themselves and examine these aspects in their natural context (Kim, 2006).

Indigenous counseling in this paper refers to at-tawazun counseling. At-Tawazun Counseling is the naming of the writer, who "discovered" a pesantren -based counseling model. The term attawazun comes from the constructs of pesantren values that can be absorbed in counseling. Attawazun comes from the fi'il madri, "tawazana" is the basic word, wazana. In the Qur'an, the pattern of the word wazana is 23 times; three verbs (fi'il) and 20 nouns (isim). The term at-tawazun comes 
from "al-wazn" (balanced) or "al-mizan" (balancing device). "Al-mizan" in the Qur'an can mean "balancing tool" - for example, God created the universe with the principle of balance (QS. ArRahman: 7) or meaning "justice" —for example, QS. Al-Hadid: 25-because the results of the scales can bring justice (Arifin, 2014a, 2020).

This paper is important —especially for counselors or social workers-so that they know the role of kiai pesantren counseling among the rogue community. By knowing the pesantren tradition, the counselors or social workers will understand the cultural values of the pesantren which can be absorbed in counseling to facilitate the community counseling process.

This study seeks to review the role of counseling carried out by pesantren in changing the behavior of the bajingan community into a person with the character "Pelopor". The focus of this paper first, relating to the quality profile of the counselor's personality. Second, procedures and techniques to convey messages in counseling. Third, the change in the behavior of the former bajingan as a person with the character "Pelopor".

\subsection{METHOD}

This research uses a qualitative research method of ethnographic-hermeneutic type. Reasons for choosing this method: First, this research reveals and describes the patterns, typologies, and cultural categories of the pesantren community. The ethnography is related to the disclosure of patterns, typologies, and categories of a community or group. Ethnography means learning from the community through cultural behavior, cultural knowledge (speech messages), and cultural artifacts from their perspective. The main purpose of ethnographic research is to try to uncover and understand various meanings that are considered by ordinary cultural actors, then researchers try to explain the new understanding gained in the culture (Fatchan, 2011; Mappiare, 2013; Spradley, 1980).

Second, this research deals with the meaning of "texts" of traditional values while hermeneutics is an interpretive concept of symbols, traditions, actions, texts, and other material forms. Hermeneutics also developed as a study of humans that aims to study cultural activities as texts and seek to gain an understanding of the expression of meaning to obtain the correct meaning (Arunachalam, 2006; Rennie, 2007).

The researcher acts as a research instrument as well as a data collector. Researchers also do full participation. The reason for choosing the location at the Pondok Pesantren Salafiyah Syafi'iyah Sukorejo in Situbondo, is because the Pesantren Sukorejo from its inception until now has carried out "counseling" among the bajingan. Pondok Sukorejo manages a rascal in a container called "Pelopor". These Pelopor members are scattered in Situbondo, Bondowoso, Jember, Surabaya, Madura, and other Madura-based communities.

Sources of data in this study: first, documents (books studied by pesantren and several books written by scholars and religious instructors at Pondok Sukorejo related to the counseling and historiographic of Pesantren Sukorejo). This written document is very important, because if we want to know a local tradition we have to analyze customs, ritual worship, and their knowledge which is also contained in the textual tradition or religious books (Kim, 2006; Woodward, 2006).

Other data sources are observation fields and in-depth interviews during the study. Some of the data is captured by the key informant technique (purposive sampling) and the purposive sampling technique and the researcher stops searching the data when the data has reached the point of "saturation". There were seven informants in this study (two kiai and five former bajingan). 
The five former bajingan are Pelopor figures in the districts of Situbondo, Bondowoso, and Surabaya.

The steps of data analysis can be simplified into three activities that occur simultaneously, namely data reduction, data display, and conclusion drawing.

\subsection{RESULTS AND DISCUSSION}

What is meant by pesantren counseling in this paper is At-Tawazun Counseling which was initiated by researchers. The term at-tawazun comes from constructs - scientific labels that are more abstract or broad in scope than concepts or overshadow some concepts (Andi Mappiare, 2009)_ "at-tawazun" (balance). The focus of at-tawazun counseling is personal and the community is not a matter of counselee. What is addressed is the human heart (personal and community), not the problem so that their hearts will be roomy, calm, peaceful and peaceful.

Because this counseling believes, if humans become a person with the character "Pelopor" then the problem by itself can be overcome. For example, if the person is already good, then he will automatically stop gambling. The kiai of Pesantren Sukorejo, never immediately told the bajingan to quit their "work", because the target for counseling was the bajingan's personality character, not his "job".

The starting point of the present is to achieve a better future life, not the counselee's past. The counselor will not look at and question the counselee's past. The past in counseling is a vehicle for mubasabah, contemplating oneself to make repentance and as a foothold for the counselee (Arifin, 2014a, 2018b, 2020; Arifin \& Munfaridah, 2018; Arifin \& Zaini, 2018).

What matters in this counseling is intention and the process is not just an outcome. Because this counseling believes the counselor's and counselee's duties are trying while the one who determines the outcome is God. Life is a process, a process of change, and always a process to change for the better.

"We must focus on the mujahadah, namely our seriousness in trying not to the solutions and results. If we have worshiped seriously, the solution will automatically open up. This is called fadhal Allah, God's gift. tawakkalna 'alallaah laa hawla walaa quwwata illa billaabil 'aliyyil adzim..." (Ibrahimy \& Arifin, 2018)

The role of counseling is an effort to nafs amarah, which always invites ugliness (with mujahadah, riyadhah, attitude of piety, and refers to goodness) to become a person with the character "Pelopor". If Sufism is more soul-cleansing, counseling is more outwardly and uses common sense.

Specifically, Al-Ghazali proposed a method of moral improvement with mujahadah (labiriyah-oriented training) and riyadhah (rubaniyab-oriented training). Because morals according to Al-Ghazali suitability of labiriyah and batiniyah attitudes. Morals are expressions of the soul that cause actions easily without being planned and forced.

But coercion through training is a method for producing morals. In the initial stages it feels "forced" but eventually becomes character and habit (Al-Ghazali, 2000). From the description of Al-Ghazali, the author sees that there is a "gap" for counseling to enter into the door of the mujahadab in the process of improving the counselee so that he becomes the best person of the people (khaira ummah).

The purpose of at-tawazun counseling is to help individuals nafsu amarah, which always invites the ugliness of being a private khaira ummah that is a person who always invites to goodness, 
prevents the evil, and believes in Allah to achieve happiness in the world and the hereafter. (Figure 1)

Kiai As'ad formulated the personal khaira ummab in the term "Pelopor" meaning "fa" means pemimpin (leader), "lam" means lillah (for God), "fa" means pemimpin (leader), "ra" means rakyat (people); namely a person who can be a leader in the way of Allah (da'wah) and a leader who fights for the people for prosperity and happiness in the afterlife(Arifin, 2020; Hasan, 2003). Thus the purpose of at-tawazun counseling contained a balance (at-tawazun) between inviting goodness and preventing badness and the balance of the goodness of present life (ad-dunya hasanab) and the goodness of later life (al-akhirah hasanah).

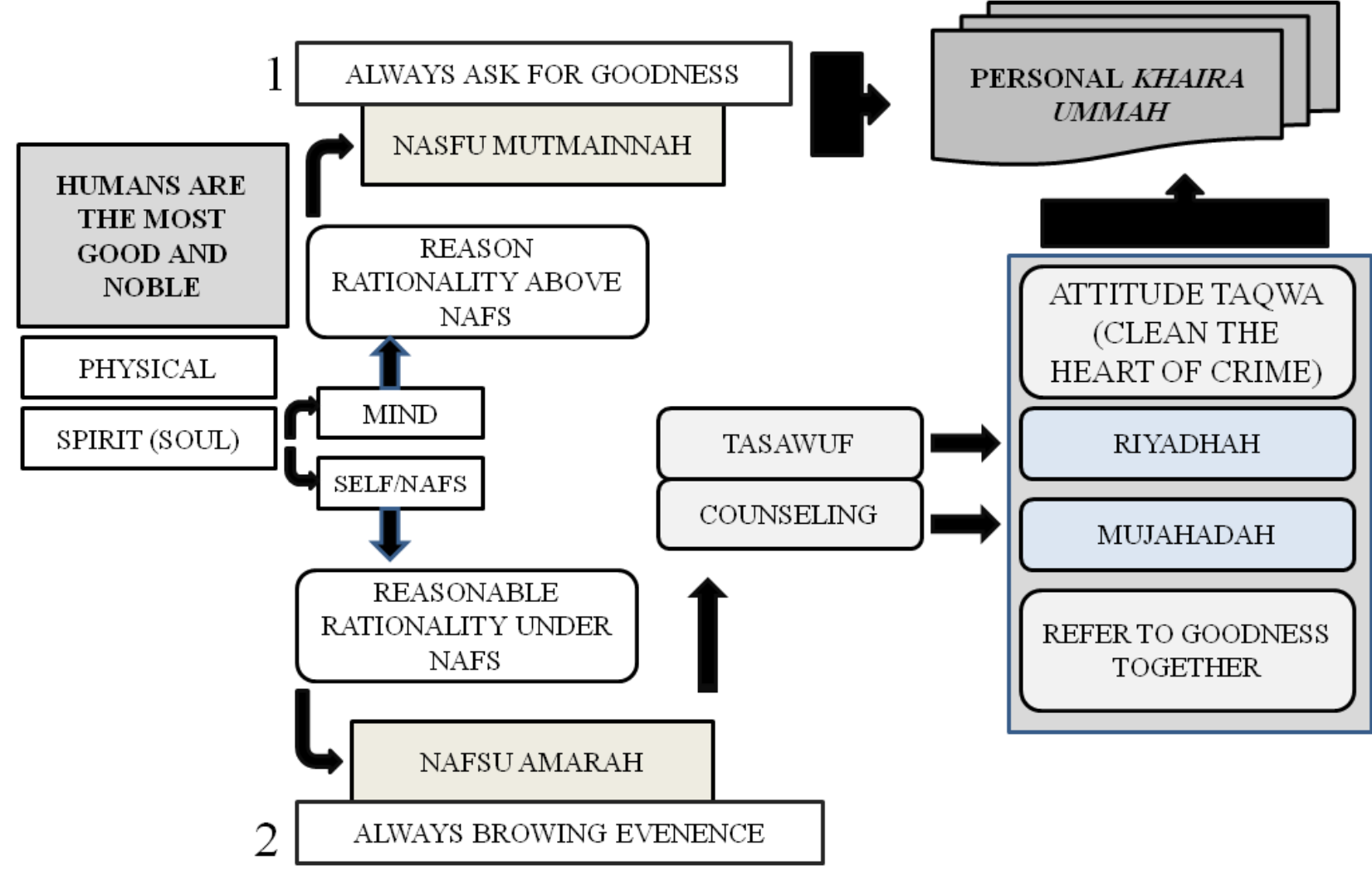

Figure 1 The role of counseling in improving personal character Pelopor

\subsection{The Quality of The Counselor's Personality}

In changing behavior, the pesantren strongly emphasizes the quality and integrity of the exemplary counselor. Pesantren emphasize, before changing others, the person who changes it must first change to be good. What's more the responsibility of the counselor is heavy but noble.

The responsibilities of the counselor, namely: first, the mas'uliyatul ilmi wal ma'rifah, namely the responsibility of science and knowledge. Second, mas'uliyatus suluk, namely the responsibility of guarding behavior, the behavior of the last. Third, mas'uliyatul khuluq, which is the responsibility of guarding character, which leads to inner behavior (Arifin, 2020). The quality of the counselor's personality includes:

a) Alim (possess and practice science) 
"The position of knowledgeable people, especially scholars in the middle of society, is like a lamp that illuminates the natural surroundings. Or like a thick shade tree, with flowers and fruit in a garden. Humans who come to the tree can take shelter under it, enjoy the flowers that smell fragrant, and also feel the fruit of the tree that has been cooked delicious" (ArRindy, 2019)

Counselors must master the science and practice it and hope for God's pleasure. Wisdom is an absolute requirement to do a job. Az-Zarnuji, believes that every Muslim is required to study social science (mu'amalah) and theories in doing work. We are also required to know some of the disadvantages and vices of the work; because whoever does not know the ugliness of work, one day he will slip to the ugliness (Alawi, n.d.)

In the book of Risalah Taubid, Kiai As'ad writes thus: "Ngamallagi ilmone klaben tekkun ben istiqamah netteppe sadeje hakkah ben sedeje larangane Allah ta'ala ejebuwi ben ma'ashi si raje ben si kene' (practice the knowledge diligently and continuously carry out all obligations and stay away from all the prohibitions of God and some immorality both large and small) (Arifin, 2020)..

For pesantren circles, practicing this knowledge is a must so that the knowledge is useful because science is practiced. So that if you only seek knowledge but not be implemented it will be in vain. Conversely, doing something without knowledge will be in vain. Because knowledge is like a tree and charity is like fruit (Al-Ghazali, 2006; Al-Jawi, 2019). Ideally, science and charity must be balanced; as indicated by Al-Mawardi: "Science is more important than charity for fools and charity is more important than science for pious people"(Al-Mawardi, n.d.).

As a result, the counselor must be alim (pious). The alim referred to here the counselor must master the science and practice it and hope for God's pleasure. If the knowledge is practiced it will always develop and be useful for the people around it to obtain happiness in life in the world and the hereafter.

b) Affection (Rahmah)

Counselors must show affection for students in daily life, both when students are in service at the pesantren or when they graduate. Affection includes aspects of labiriyah and batiniyah. So that the relationship will be "asambung (continued)", his heart merges with the student.

In the moral books that are taught in pesantren always emphasize that teachers always love and love their students. For example, in the book Adab al-Alim wa al-Muta'allim by Kiai Hasyim Asyari explained, one of the manners of a teacher is to love his students as he loves himself. According to Kiai Hasyim, one of the manners of the pious towards his rights, including:

"So that (the alim) associate with humans with noble morals: beaming face, starting greetings, giving food, holding anger, not hurting humans, being responsible, respecting and not asking for respect, respect and not (asking others) respect to him, thanking virtue, making happy ... helpful and gentle to those in need, love for family and relatives, loved his students, helping them, and doing good to him " (Asy'ari, n.d.).

The attitude of the teacher's affection for the students will give birth to the students $t a^{\prime}$ zhim. So, there is an interpersonal relationship between teacher- students. Even this interpersonal relationship is not just an outer relationship but also touches the inner self. For example, after each prayer or will learn the students pray for the teacher. Likewise, the teacher prayed for the student, to gain blessed knowledge. Author Kharisma Kiai As'ad said thus: 
"According to Kiai As'ad; a kiai must connect — his heart must be one — with the students. Likewise, a students has to be connected with the kiai. From here later, barakah will emerge; so that the message of the kiai will always be remembered and remain embedded in the hearts of the students or the community "(Hasan, 2003).

According to Kiai Azaim, one indication of affection is a sincere charming smile. Kiai Azaim explained about the power of a smile of love:

"A smile is an expression of one's inner joy. And the heart of every Muslim who has been flowed from the faith from the field of charity goodness, will foster happiness and ultimate peace, or also called hayâh thayyibah ... A smile of laughter that appears on the surface of the face is the activity of the human body as a representative of feelings of care or affection arising from the lower layers of his mind ... Because of that the smile is a very deep "hidden power", and its activity is a valuable charity that nourishes the body to stay healthy. It is true that His Majesty's words. "Your smile on your brother's face is (worth) alms to you." ... The power of a smile of laughter when managed properly will defeat even the sharpness of the sword. " (Ibrahimy \& Arifin, 2019)

The attitude of affection of kiai Sukorejo to the bajingan as his da'wah partners was the same as the affection relationship between the teacher-santri. The relationship is labiriyab-batiniyab and exists for all time; therefore they are collected in the Pelopor container.

c) Sabar (Patience)

Patience means an attitude of grace and courage to face difficulties. So that the counselor has the resilience to suffering without complaining and will reach maturity. According to AlHaddad, true faith can be classified into two; patient and thankful (Al-Haddad, 2005). Therefore, believers must be patient when a disaster strikes while remaining calm and graceful. They also must be patient in undergoing obedience by not being lazy and trying to perfect that obedience. They must be patient in controlling their passions. Ibn Atha'illah gave a description so that we are always patient when hit by hardships.

"Allah gives you space so that you are not always in narrowness. God gives you a narrowness so that you do not drift off in the field. God releases you from both so that you do not depend on you except Allah. " (Ar-Rindy, 2019)

When struggling in the midst of society, one of the keys to his success is also being patient. The biographer Kiai As'ad writes thus:

"In Kiai As'ad's view, challenges in the community included an unwritten test that a kiai must face. The toughest test and many can not stand, usually if tested by ear or vilified. If the person is emotional and angry, the community will clearly be left behind. Whereas a kiai is khadim al-ummah, a public servant. Therefore all tests and challenges must be faced with patience and perseverance. And most important, is how to deal with the community not from making decisions to the community. "If you want to have followers, help the community even though it's bitter," he added. (Hasan, 2003)

In the context of counseling, counselors should be patient. Because the essence of patience is grace and courage to face difficulties. Patiently, we will reach maturity. Patiently, we have the resistance to suffering without complaining. Patiently, we reach the essence of faith. Patiently, we demonstrate the quality of humanity that is able to tame anger and lust (An-Najar, 2001). 


\section{d) Wara' and Zubud}

Wara' means an attitude of self-control and caution by leaving something that is doubtful (syubhat) and which is less useful and be kind to others. Zubud means a simple attitude and more concerned with the interests of others (altruistic). The essence of zubud is to eliminate worldly values, fascination with it, and free the soul from the gratification of desires and pride. In other words, zubud will give birth to the nature of honesty that is his actions without strings attached and his words without lust.

According to the Hikam author, wara' is one of the noble qualities to not be too attached to the needs of the world, to accept sincerely what is in his hands, to feel grateful for all that he has, and not to envy others. Wara' is able to destroy excessive desire. Wara 'will give rise to a simple and qana'ah nature (to feel sufficient). Wara' will cause calm in facing life's problems (Ar-Rindy, 2019).

Wara' is the beginning of zubud. People who zubud will not feel proud of the pleasures of the world and will never complain because of losing the world. According to Yahya bin Mu'adz, the essence of zubud is first, the person whose actions are unconditional. Second, the words that came out without the desire of lust. Third, he has glory without power. According to Al-Muhasibi the lives of people who are zuhud are those who leave lust, cleanse themselves from the dangers of lust, inviting the soul to do what science advises, do not like to relax, and increase the ethos in good deeds (Al-Muhasibi, 2001; Al-Qusyairi, 1998). The book of Al-Hikam says this:

"... in zuhud men will be better able to reflect about himself, and the pleasure of God he receives. Zuhud people are people who are able to control the nature of humanity in the association of the life and in regulating his world life. In a person who is patented by the sense of security, because he does not need to chase or be pursued by the hassles of the life of the world ... he lives qana'ah, because living like that is part of the lives of zahid people. " (Ar-Rindy, 2019)

Wara' and zuhud are including maqam or stages of the path that a Sufi must pass. The Prophet advised, that we approach the people of zuhud and talk. Because he will teach wisdom (Al-Qusyairi, 1998). Kiai Hasyim Asy'ari puts the attitude of the wara and zuhud as one of the manners of the pious (Asy'ari, n.d.).

\section{e) Ikhlas dan Tawadbu'}

Ikhlas (sincere) means that you will not feel the difference when you receive praise and scolding, do not look at his deeds, and do not demand merit. Be sincere in a sincere attitude, cleanse yourself, and purify the heart from other than God. Tawadhu ', an attitude that does not consider others ugly and considers himself superior. People who are tawadhu 'are people who always respect and accept the truth from others.

According to Al-Ghazali sincerity has three pillars. The first pillar as a sincere foundation is intention. Intentions are motivations that drive abilities that arise from knowledge. Knowledge arises motivation, motivation arises ability, then the ability to help motivation moves members of the body to do something. The second pillar, the sincerity of intention, that is one or pure motivation. The third pillar, honesty which is the perfection of sincerity (Al-Ghazali, 2000).

According to Atha'illah, human charity depends on the situation and conditions that enter the human heart. A charity framework is a clear act, while the spirit is sincere. A charity is determined by how someone puts his intention when doing charity worship. Ikhlas is the spirit of charity and charity shows the upholding of faith (Ar-Rindy, 2019). 
Kiai Hasyim Asy'ari puts the attitude of tawadhu' always as one of the manners of the pious (Asy'ari, n.d.). He also explained, teachers should also tawadhu' to their students. According to Kiai As'ad, sincerity is the key to success and tawadhu' including the path that must be passed for educators (Arifin, 2014b; Hasan, 2003).

As for those who are tawadhu ', according to Abu Yazid, are people who do not see themselves as having a position and do not view others as bad. According to Ibn Atha ', tawadhu' is a person who accepts the truth from others (Al-Qusyairi, 1998). Tawadhu' for ordinary people means feeling well dressed, in residence, and driving simple. As for tawadhu ' for a typical person, it means getting used to accepting the truth from anyone (Al-Ghazali, 2000).

\section{f) Communicative}

Counselors must have a strong mass base below while having a strong network. So that some guidance and counseling programs run as expected; as depicted in the Qur'an Ibrahim Surah verses $24-25$ which is about the criteria of a good tree.

In the context of building networking "interpretation" of the verse, thus: First, it has a firm root that has a strong-rooted mass base. Second, it has branches that soar up to the sky; it means to have a wide network and great influence at the top level (for example principals and organizations). Third, have fruit that can be picked every season; the intention is to benefit the organization and society (Hasan, 2003).

One of Kiai As'ad's messages to students of Sukorejo who would stop boarding school was for him to practice his knowledge in the mushalla around his house. One of the meanings behind the message, santri Sukorejo is to master the center of networking and interaction with the community. Because the mosque or mushalla in the countryside is one of the centers of communication and a gathering place for the community. A mosque or mushalla is a cultural sphere that brings together various segments of society, which can produce a distinctive culture (Nursyam, 2005).

\subsection{Procedure and Technique of Message Delivery in Counseling}

The procedure for changing behavior is first, establishing a relationship. At this stage, the kiai of Pondok Pesantren Sukorejo contacted several kiai langgar (mushalla) in rural areas. The kiai asked them to look for bajingan figures in their respective regions and then they were expected to gather together with the bajingan to the Pondok Pesantren Sukorejo.

The other way, the kiai sends some of his students to establish relationships with some bajingan. Then together with the conquered bajingan, he visited Sukorejo. Kiai also uses Pelopor members to find new members. Even the kiai often seek out bajingan figures to fight and preach. At this stage, the kiai gives good news and "guarantees" to the bajingan. Kiai considers them as family members and gives a kind of guarantee for a lifetime, to anyone, including even the most sinful bajingan, if they join Kiai Sukorejo.

At this stage of the relationship, the counselor interacts with the counselee to open the counseling process. The counselee goes to the counselor to convey the problem or vice versa, the proactive counselor comes to the counselee to help them. At this stage of establishing a relationship, the counselor should deliver good news and guarantee the counselee so that the counselee feels comfortable and safe.

In doing this approach, the counselor and counselee must introduce themselves to one another to support the smooth process of changing behavior. The counselor specifically 
introduces himself, as an initial effort for effective communication by showing credibility (a set of perceptions about some counselor's strengths, for example about his competence), attractiveness (something that can lead to the liking and attractiveness of the counselee), and power (an ability that can lead to compliance, for example, expertise.)

Second, develop relationships. The Kiai takes a more in-depth approach through silaturrabim or bringing bajingan into members of the "Pelopor" organization. He doesn't care even though they are bajingan, as long as they are close and close. This rascal by the kiai was involved in religious events and boarding schools. For example, they are told to foster and maintain their environment and if there is a study session, the task is to coordinate the surrounding community. It is not uncommon for the Pioneers to encourage their children and neighboring children to board at Pondok Pesantren Sukorejo. Because it is close and the kiai always give subtle remarks, so that finally the bajingan figures are aware.

Third, the intervention or stage of action. In the context of counseling, the counselor has a good relationship and provides counseling services using techniques following the counselee's orientation to the benefit. At this stage, it must balance all elements and potential within the counselor, counselee, and environment that refers to the benefit.

In this stage of the action, the main goal is to train the heart to repent. One cleric of Pesantren Sukorejo, described thus:

"Training the heart is a process of clarifying morals, humiliating lust and pinning on selfservitude. Getting used to feeling inferior and despicable before the Creator will burn the diseases that are always eating away at him ... to form a clean and clear heart requires serious effort by rubbing the impurities in the form of a despicable nature. If it cannot be eliminated all at once, it needs to be done in stages. Begin by cleaning the mildest despicable traits and consistently proceed with the heavier ones until they are completely used up. Besides, the heart needs to be trained by getting used to organize noble morals. But if the various efforts offered above are still not able to improve the heart, for example by reading the Qur'an and multiplying dhikr still have not succeeded in healing the heart, then it is very possible that the mistake is not in the concept offered, but the effort we have tried has not been done maximum (Yasid, 2007).

One way to cleanse the heart with riyadhah (gerbat) in the form of wirid and istighatsah. The Pesantren Sukorejo considers that if gerbat is done properly and correctly, it will affect the behavior of those who commit it. Gerbat in general has two parts. First, the format of birth (shurah zahahirab), namely all acts of worship. Second, the deepest essence (baqiqah bathinah), that is, the nature that does not appear as sincere, solemn, and khudhu' in the presence of Allah. Because worship is

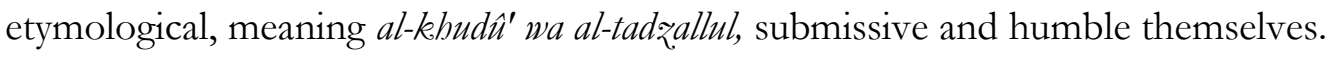

Fourth, follow up plans. At this stage, the counselor and counselee plan the program or action after the intervention. For example, counselees are encouraged to remain active in activities organized by the Pesantren Sukorejo and Pelopor. In this pesantren-based counseling, there is no "termination" stage because the counseling process is carried out continuously and istiqamah so that the counselor-counselor relationship is maintained throughout the time.

The former bajingan are expected to practice their knowledge in the midst of society. Kiai Fawaid said, like a diesel lamp, Pondok Pesantren Sukorejo was the engine while the santri were lights that illuminated the people from the dark. Therefore, the lights must always be connected to the engine. In order to stay connected, Pelopor members must often meet with Pesantren Sukorejo or join the Pelopor organization's activities.

Page | 68 
The techniques for conveying messages in counseling include:

a) Targhib: guarantee for a lifetime

A lifetime guarantee, including one of the techniques to generate interest and enthusiasm (targhib), which is often used by Pesantren Sukorejo to change one's behavior. In arousing enthusiasm, the Pesantren Sukorejo combines elements of optimism and pessimism, between anxiety and hope (khauf and raja), between targhib (reinforcement) and tarbib (punishment).

According to Imam Al-Ghazali, this targhib is very important to arouse desire in obedience. Imam Al-Ghazali described thus:

"In matters of worship generally revolves around two things: first, doing obedience, second, away from immorality. Both will not run smoothly as long as the passion that drives evil is still attached. And the solution is by way of targhib and tarhib, which is full of hope and fear ... if lust is brought to worship and piety, he must be given hope in heaven and reward and fear of hell and torture. For that, $\mathrm{O}$ travelers of worship, you should familiarize yourself to remember his lust with these two things, if not, then his lust will not be willing to worship. This is what causes the Qur'an to mention so many verses about promises and threats. The promise of beauty will be obtained for those who obey and the threat of painful punishment for those who are ungodly. If the feelings of khauf and the king have been possessed, then smoothly perform worship, far from feeling lousy and suffering in picking up divine grace" (Al-Ghazali, 2006)

Kiai As'ad also often uses this targhib technique to subdue the hearts of bajingan. Kiai As'ad always aroused their enthusiasm while guaranteeing that they would be semati-semati, as long as they followed the kiai As'ad.

"Sapa bei bajingan se ngelakone dusa se paling hebat tape norok tang perintah, bung tabung sabbu'pagike neng akhirat, montada' e suarge engkok senyareah (Whoever is the bajingan who commits the greatest sin, but follows my orders, in the hereafter will join me, if not in heaven, I will search!)" (Hasan, 2003)

Such was the kiai As'ad dawk before the bajingan. Words from a great kiai even someone considered a guardian; who will still gather - even more than that, "sabbu-tubes", a term that is difficult to Indonesians - in heaven will be an unparalleled speech of heart conditioning for them. For sinful people; cheating, playing with women, stealing and taking the lives of innocent people. This lifetime guarantee is of great significance to them.

b) Message according to their language

Techniques to convey messages following their language, meaning in conveying messages, counselors must deliver messages according to their level of understanding (worldview) and be empathetic so that the messages can touch the bottom of their hearts. The counselor conveys verbal and nonverbal messages must be accompanied by sincere intentions.

The author of the book Kharisma Kiai As'ad in the Eyes of the People explained that one of the recipes for the success of Kiai As'ad in managing Pioneers was his expertise in communicating with bajingan.

"Indeed, if we want to attract the sympathy of bajingan we must understand and use their language too. Understanding the language here, namely the passage of symbols both through verbal expression and action (sign). For example the language of the Madurese-Javanese, the language of the intellectual-laity, the language of the strong-weak, and the language of the 
restless-happy. Therefore, it is very interesting if we study the word of God, in the Surah Ibrahim verse 4, "We did not send an apostle, but in the language of his people, so that he could explain to them clearly". Likewise Kanjeng Prophet Muhammad SAW's message, "We, the prophets, are ordered to place people according to their position and talk to them according to the capabilities of their minds."(Hasan, 2003).

Communication following the language of the former bajingan in the context of the Qur'an can be in the form of the first, Qawlan baligha (QS An-Nisa': 63), which is speaking using expressions that are striking, precise, clear and imprinted in the heart. Secondly, Qawlan ma'rufa (Al-Baqarah: 263), namely speaking in words that are heartening and not offensive. Third, Qawlan Sadieda (QS al-Ahzab: 70), which is true and honest speech. Fourth, Qawlan kariman (QS Al-Isra ': 23), namely speaking with noble words, full respect, reflecting noble character. Fifth, Qawlan layyinan (QS Thaha: 44), which is speaking with a gentle and humble heart. Sixth, Qawlan maysuran (QS Al-Isra ': 28) is to speak well and properly, speak simply, easily understood, and not convoluted (Arifin, 2018a, 2020).

\subsection{The Behavior of the Former Scoundrel "Pelopor"}

First, as an example for the community. Pelopor members play an active role in inviting the surrounding community and community in the Islamic da'wah movement. They joined in prospering and enlivening activities at the mushalla or mosque and NU organization. According to some former bajingan, if he was already a member of the Pelopor; This is a pride because it has entered into the big influence of Kiai As'ad and his children and Pesantren Sukorejo and at the same time bears the responsibility to uphold as a member of the Pelopor. Therefore, he maintains his behavior to always do good and be an example for others.

In conquering bajingan figures, Kiai As'ad uses the strategy "megha' kalemmar aéngnga sé ta' lekkoa (catching waders but not getting muddy). "This means, Kiai As'ad conquered bajingan figures. If the character succumbs, his subordinates come along. In conquering these bajingan figures, Kiai As'ad does not use violence, that is, the environment does not become murky. This strategy aims, the bajingan figures will be a good role model for the community. The purpose of this strategy, perhaps in behavior counseling is known as social modeling techniques and live peer models (Gerald Corey, 2009).

Second, as a motivator and inviter of many friends, neighbors, and parents so that their children be lodged in the Pesantren Sukorejo. Some bajingan figures, after becoming members of Pelopor, they put their children and relatives in Sukorejo. This role was carried out since the first years of the founding of the Pesantren Sukorejo. It was this Pelopor member who preached Pesantren Sukorejo by word of mouth during the community.

Third, as a contributor in the construction of pesantren.. The kiai used the services of the Pelopor members to build his pesantren.. For example by asking for their help to look for donations of bamboo and side dishes in the construction of pesantren..

According to Pak Mustarib, Kiai As'ad was indeed in building his pesantren., always asking Pelopor for help in finding bamboo. "I ask for the help of Pelopor in building this pesantren.. Why? Maybe those who are still happy to play, because they helped find bamboo, will stop playing. Those who still love to steal, will stop being thieves thanks to helping the pesantren," kiai As'ad dawned, one day, in front of Mr. Mustarib (Arifin, 2014a).

Fourth, participate actively in maintaining the security of pesantren, especially during critical times (for example during the election) and at religious memorial events in Sukorejo. The ability 
of the former bajingan, by Kiai As'ad, was also used to maintain the security of his pesantren. Pelopor members are also active in maintaining the security of a study activity in several areas, when the preacher from Pesantren Sukorejo.

Fifth, as "intel" Kiai Sukorejo. This Pioneer member always monitored the existence of students, Sukorejo, NU developments, and social problems in the community and then reported them to Kiai Sukorejo. Kiai Sukorejo in following social development also utilizes information from Pelopor members. Kiai Sukorejo uses this information as comparative data from some information coming from other parties; for example some NU management and community leaders. So that Kiai Sukorejo knew the real situation in the community. Even to check the truth, Kiai Sukorejo did not hesitate to go straight in.

Sixth, in the era of struggle, this former bajingan was actively involved in defending Indonesia's independence. They joined in fighting with Kiai As'ad in the eviction of Japanese troops in Garahan Jember, late September - early October 1945; took part in the November 10 battle in Surabaya; committing theft of weapons in the Dutch gunpowder building in Bondowoso and Situbondo areas; and guerrilla warfare in maintaining RI's independence (Hasan, 2003).

From the change in behavior of the former bajingan, it appears that the bajingan did not just change for himself but also changed for his community and society for the better. This is following the meaning of "Pelopor" themselves who are expected to be the foremost leaders in preaching as well as leaders in building together the community; there is a vertical relationship with God and a horizontal relationship with fellow Muslims; there is a ritual shift and a social shift.

I agree with the person who says that the person who is rightfully ritualized must be socially righteous. This departs from the doctrine that prayer and other rituals when performed sincerely, solemnly, and $k h u d h u^{\prime}$ in the presence of al-Ma'bud certainly give birth to social sensitivity, humility, and compassion for others and to eliminate the qualities despicable like miser, selfishness, arrogant, and so on. (Arifin, 2020).

Some of the qualities of the counselor's personality can be drawn into the at-tawazun (balance) construct between "shalahiyyah" and "shalih". This "shalahiyyah" refers to scientific skills and counselor skills; for example pious and clever communication. "Salih" refers to the strength of the moral integrity of the counselor's personality; for example zuhud and sincere.

For pesantren, the ability in "shalahiyyah" and "shalih" behavior is not just to achieve success in life in the world but also to achieve happiness in the hereafter. Therefore, "shalahiyyah" and "shalih" is intended to achieve the pleasure of God. Ar-Rindy argues, the combination of shalabiyyah and shalib and bidayah and inayah Allah will facilitate the entry of God's light into the souls and hearts of people (Ar-Rindy, 2019).

The at-tawazun construct on the technique of conveying the message, there is a balance between targhib and tarbib, between reinforcement and punishment, between optimism and pessimism. The goal, so that the bajingan have a balanced spirit between hope and a sense of worry. The counselor conveys messages following his parish language, must be balanced between verbal and nonverbal messages with all my heart; there is a balance of labiriyah and batiniyah attitudes. Whereas the construct of at-tawazun on changes in the behavior of former bajingan, there is a balance between ritual and social righteousness, a balance of vertical relationships with God and horizontal interaction with fellow creatures of God.

Some research in the field of counseling also supports the construct of at-tawazun. Yuen's research one of his conclusions explains that positive changes occur in the counselee when they 
are interrelated between elements of labiriyah and bathiniyah namely: spirituality, identity, beliefs, potential, behavior, and environment (Yuen, 1993).

Similarly, research conducted by Ibrahim (2011). According to Ibrahim counselors who conduct counseling to Muslim counselees in the United States, must pay attention to elements of labiriyah and batiniyah. First, the counselee's cultural identity (for example, sex and race). Second, worldview (beliefs, values, and assumptions of the counselee). Third, the stages and types of acculturation. Fourth, its commitment to Islam (Ibrahim \& Dykeman, 2011).

Corey agrees. According to Corey, effective counseling involves elements of the body, mind and spirit. In the counseling process in the field, spiritual and religious issues must not be ignored. Because, according to Corey, religion and spirituality are often the problem of the counselee as well as the best solution (Gerald Corey, 2006). Because religious values and spirituality play an important role in life. Spirituality is an important component for mental health and includes being able to improve the therapeutic process in counseling practice (Gerald Corey, 2009)

The concept of at-tawazun is similar to the concept of congruence in person-centered counseling. Congruence is the most basic and most important characteristic in Rogers's concept. Because congruence is the foundation of the counselor in being empathetic and unconditional positive regard. Congruence is one of the necessary and adequate conditions for changing personality; namely the counselor in a state of harmony or integrated in a counseling relationship.

Congruence means real skilled counselors, which means intrinsically integrated and authentic during the counseling process. Congruence means there is harmony between inner experiences (feelings, emotions, and dreams) with expressions in counseling. Congruence can help the counselee's trust in counseling relationships. Congruence can facilitate the flow of positive energy in counseling relationships. If the indications for speech, intonation, and gestures are in harmony, then communication will be clearer and easier to understand (Gerald Corey, 2009; Gillon, 2007; McLeod, 2003; Rogers, 1942).

Implementation of pesantren cultural values (which are constructed in at-tawazun) into counseling, is loaded with religious meaning. This is by the concept of indigeneous counseling, which one of its characteristics emphasizes psychological phenomena in the context of religion and culture (Arifin, 2018a, 2020; Arifin \& Zaini, 2018). Even religion is an aspect and object of study that is essential in indigeneous counselling (Kim, 2006).

Spirituality and religion are the core aspects of people's identities in some cultures. Spirituality and religion play an important role in shaping individual beliefs and behavior (Froma Walsh, 2009; Henriksen, 2015; Loewenthal, 2007; Maurice, 2010; Podikunju-Hussain, 2006). Because after all the religions for thousands of years have binded people in maintaining a cultural perspective. Religion provides explanations and shows the values of phenomena that cannot be explained. Religion and behavior are inseparable (Samaovar, 2010).

The importance of spirituality and religiosity in counseling is supported by several studies. Propst research results conclude that ignoring the counselee's religious beliefs can reduce the effectiveness of counseling and increase early termination. He also explained that non-religious therapists will get the best results when using a religious approach (Propst, 1980).

Some recent surveys in the United States also show that combining spirituality with religion in individual and group counseling processes (Chou \& Bermender, 2011; Post \& N, 2014; Walker, 2012). Religion and spirituality also function effectively as a bull of defense as well as healing from 
crime and narcotics. Especially in the context of Indonesian religious society, offers of counseling that require religious values are very necessary.

\subsection{CONCLUSION}

The quality of the kiai's personality, as a counselor, is in the at-tawazun construct: there is harmony between the quality of shalabiyyah (scientific prowess and skills) and the integrity of shalih (strength of character). For boarding schools, the ability of shalabiyyah and shalib behavior is not just to achieve success in life in the world but also to achieve happiness in the hereafter.

In the message delivery technique, there is a balance between targhib and tarbib, so that the ex-bajingan has enthusiasm and optimism that his repentance will be accepted by God as well as worry is not received so that he is more diligent in doing good. Likewise the kiai convey messages according to their language (the internal frame of reference), their level of understanding (worldview), and be empathetic so that their messages can touch their hearts; there is harmony between labiriyah and batiniyah attitudes.

Whereas the construct of at-tawazun on changes in the behavior of the former bajingan, there is a balance between ritual and social shalih. Former bajingan don't just worship for cleaning themselves up but also invite their communities to build civilization with the surrounding community.

At-tawazun counseling includes comprehensive counseling; sourced from religious values and best practices among pesantren. This pesantren counseling combines elements of labiriyah and batiniyah, worldly and ukhrowi, body and soul. This counseling should be developed in several educational institutions or social institutions, especially psychology and counseling.

\section{List of Reference}

Al-Ghazali. (2000). Prinsip Dasar Agama Terjemah Kitabul Al-Arba’in fii Usbuliddin. Jakarta: Pustaka Al-Amani. Al-Ghazali. (2006). Metode Menjernibkan Nurani Terjemah Minhajul 'Abidin. Bandung: Hikmah.

Al-Haddad, A. . (2005). Terjemah an-Nashaih ad-Diniyyah wa al-W asaya al-Iman. Yogyakarta: Mitrapustaka.

Al-Jawi. (2019). Terjemah Maroqil 'Ubudiyah Syarah Bidayah al-Hidayah. Surabaya: Mutiara Ilmu.

Al-Mawardi, A. . (n.d.). Adab ad-Dunya Wa ad-Din. Situbondo: Assyarif.

Al-Muhasibi. (2001). Renungan Suci Bekal Menuju Takwa (Terjemah Al-Washaya). Jakarta: Pustaka Azzam.

Al-Qusyairi. (1998). Risalah Qusyairiyah. Jakarta: Pustaka Al-Amani.

Alawi, A. . (n.d.). Sullam at-Taufiq. Surabaya: Maktabah al-Hidayah.

An-Najar, A. (2001). Ilmu Jiwa dalam Tasawnuf Studi Komparatif dengan Ilmu Jiwa Kontemporer. Jakarta: Pustaka Azzam.

Andi Mappiare. (2009). Dasar-dasar Metodologi Riset Kualitatif untuk Ilmu Sosial dan Profesi. Surabaya: Jenggala Pustaka Utama.

Ar-Rindy. (2019). Terjemah Syarah Al-Hikam Ataillah. Situbondo: Assyarif.

Arifin, S. (2014a). Sang Pelopor: Kisah Tiga Kiai dalam Mengelola Bekas Bajingan. Surabaya: Pena Salsabila.

Arifin, S. (2014b). Wejangan Kiai As'ad dan Kiai Fawaid. Surabaya: Pena Salsabila.

Arifin, S. (2018a). Komunikasi Kiai Pesantren: Pemberdayaan Komunitas Bajingan Perspektif Komunikasi Konseling. 2nd Proceedings Annual Conference for Muslim Scholars, (April), 330-338. Surabaya: Kopertais 
IV.

Arifin, S. (2018b). Menjadi Warga Negara Khaira Ummah Dengan Hidup Sehat Tanpa Korupsi. Jurnal Konseling Religi, 9(1), 39-60.

Arifin, S. (2020). At-Tawazun: Psikologi dan Konseling Berbasis Pesantren untuk Membentuk Karakter Khaira Ummah. Malang: Literasi Nusantara.

Arifin, S., \& Munfaridah, H. (2018). Pengembangan Desain Konseling Berbasis Pesantren dengan Pendekatan Service-Learning. Jurnal Bimbingan Dan Konseling Islam, 08(02), 110-132.

Arifin, S., \& Zaini, A. (2018). Dakwah Inklusif di Kalangan Bajingan : Membedah Komitmen Bekas Bajingan dalam Membangun Peradaban Perspektif Psikologi Sosial. Jurnal Dakwah, XIX(1), 29-50.

Arunachalam, M. (2006). A Philosophical Hermeneutics Approach for Understanding Community Dialogue on Environmental Problems: A Case Study of Lake Taupo. The 5th European Conference on Research Methodology Tgl 17-18 Juli. Retrieved from www.academic-conferences.org

Asy'ari, M. H. (n.d.). Adab al-Alim wa al-Muta'allim. Situbondo: Assyarif.

Chou, W. -M., \& Bermender, P. A. (2011). Spiritual Integration in Counseling Training: A Study of Students' Perceptions and Experiences. Vistas, 11. Retrieved from http://counselingoutfitters.com/ vistas/vistas11/Article_98.pdf Acess date: 9 January 2020

Fatchan. (2011). Metode Kualitatif Beserta Contoh Proposal Skripsi, Tesis, dan Desertasi. Surabaya: Jenggala Pustaka Utama.

Froma Walsh. (2009). Spiritual Resources in Family Therapy. New York,: Guilford County Schools.

Gerald Corey. (2006). Integrating Spirituality in Counseling Practice. Vistas, 06. Retrieved from http://www.counseling.org/ Acess date: 9 January 2020

Gerald Corey. (2009). Theory and Practice of Counseling and Psychotheraphy. Belmont: Thomson Higher Education.

Gillon, E. (2007). Person-Centred Counselling Psychology: An Introduction. London: SAGE Publications Ltd.

Hasan, S. A. (2003). Kharisma Kiai As'ad di Mata Umat. Yogyakarta: LkiS.

Henriksen, C. E. J. (2015). Counseling Students' Perceptions of Religious/Spiritual Counseling Training: A Qualitative Study. Journal of Counseling \& Development, 93, 59-69.

Hudaeri dkk. (2002). Tasbih dan Golok: Studi tentang Kharisma Kyai dan Jawara di Banten.

Ibrahim, A. ., \& Dykeman, C. (2011). Counseling Muslim Americans: Cultural and Spriritual Assessments. Journal of Counseling \& Development, 98, 393.

Ibrahimy, A. A., \& Arifin, S. (2018). Kiai Fawaid As'ad: Kepribadian, Pemikiran, dan Perilaku Politik. Situbondo: Tanwirul Afkar.

Ibrahimy, A. A., \& Arifin, S. (2019). Risalah Hati: Trilogi Biografi Nyai Zainiyah As'ad. Situbondo: Tanwirul Afkar.

Kim, U. (2006). Indigenous and Cultural Psyichology. New York,: Springer Science.

Kosim, M. (2007). Kyai dan Blater (Elite Lokal dalam Masyarakat Madura). Kasrsa, 12(2), 161-166.

Loewenthal, K. . (2007). Spirituality and Cultural Psychiatry. In D. Bhugra \& K. Bhui (Eds.), Textbook of Cultural Psychiatry. New York,: Cambridge University Press.

Mappiare, A. (2013). Tipe-Tipe Metode Riset Kualitatif: untuk Eksplanasi Sosial Budaya dan Bimbingan dan Konseling. Malang: Elang Emas.

Page | 74 
Maurice. (2010). Service Learning Handbook. North Carolina: Guilford County Schools.

McLeod. (2003). An Introduction to Counselling Third Edition. New York,: Open University Press.

Nursyam. (2005). Islam Pesisir. Yogyakarta: LKIS.

Podikunju-Hussain. (2006). Working With Muslims: Perspectives and Suggestions for Counseling. VISTAS Online, 22, 103-105.

Post, B., \& N, W. (2014). Client Perspectives About Religion and Spirituality in Group Counseling. The Counseling Psychologist, 42, 601-627.

Pribadi. (2014). The Historical Roots and Identities of Local Strongmen Groups in Indonesia. Journal of Local Culture, 1(2), 104.

Propst, L. R. (1980). The Comparative Efficacy of Religious and Nonreligious Imagery for The Treatment of Mild Depression in Religious Individuals. Cognitive Therapy and Research, 4, 167-178.

Raditya. (2011). Politik Keamanan Jagoan Madura. Studi Pemerintahan, 2(1), 98-131.

Rennie, L. (2007). Hermeneutics and Humanistic Psychology. Jurnal The Humanistic Psychologist, 1, 5-16.

Rogers, C. R. (1942). Counseling and Psychotherapy Newer Concepts in Practice. Cambridge: The Ribersibe Press.

Rozaki, A. (2004). Menabur Kharisma Menuai Kuasa, Kiprah Kiai dan Blater sebagai Rezim Kembar di Madura. Yogyakarta: Pustaka Marwa.

Samaovar, L. . (2010). Komunikasi Lintas Budaya. Jakarta: Salemba Humanika.

Saruhan, V. (2019). Transactional Analysis Theory and Spirituality The Basic Philosophy of Transactional Analysis. Spiritual Psychology and Counseling, 4, 321-331. https://doi.org/10.12738/spc.2019.4.3.070

Spradley, P. J. (1980). Participant Observation. New York,: Holt Rinehart and Winston.

Walker, E. (2012). The Misunderstood Pastoral Counselor: Knowledge and Religiosity as Factors Affecting a Client's Choice. VISTAS Online, 6.

Woodward, M. . (2006). Islam Jawa: Kesalehan Normatif Versus Kebatinan. Yogyakarta: LKIS.

Yasid, A. (2007). Fiqh Today: Fatwa Tradisionalis untuk Orang Modern Buku Keempat: Fikih Tasawnf. Jakarta: Erlangga.

Yuen, M. (1993). On Empowering Clients to be Responsible Person: Reflections on my Counseling Approach. Asian Journal of Counseling., 2(2), 36. 